Journal of Economics and Behavioral Studies

Vol. 7, No. 1, pp. 50-63, February 2015 (ISSN: 2220-6140)

\title{
Malaysian Consumer Research: Does Computer Literacy Affirmative towards E-commerce Activities?
}

\author{
Dileep Kumar M., Harvi S., Normala S. Govindarajo \\ Othman Yeop Abdullah Graduate School of Business, Universiti Utara Malaysia \\ prof.mdk@gmail.com
}

\begin{abstract}
Rapid expansion of technology application, especially in the field of information technology, with the support of fine tune infrastructure, further correlated with severely with the ecommerce activities. This scenario is not much different in developed as well as developing countries. It is a placid trend nowadays that the customers are moving from traditional direct shopping practices to online shopping. In this scenario it is observed that the generations $\mathrm{Y}$ is more contented with online purchasing and adoption of e-commerce practices compare to generation X. It is hypothesized in this research that higher the computer literacy people have with higher the attitude in favor for technology adoption and ecommerce activities. Contextualizing this assumption to Malaysian scenario, fewer studies have been conducted so far and seldom any information that has shared across to the research world. Hence, a study was conducted to analyze the effect of computer literacy on internet usages and ecommerce activities among generation $Y$ in the Malaysian context. This study provides interesting insights into the technology adoption aptitude of generation Y.
\end{abstract}

Keywords: Generation Y, internet usage, gender, computer literacy and ecommerce

\section{Introduction}

The huge numbers of internet users in the world and supportive telecommunication infrastructure almost all over the world has attracted the companies and bring their business into a digital era, turning their business from 'brick and mortar' to 'brick and clicks' or even 'fully e-commerce' which has no physical presence, where customer can buy or sell directly. Survey conducted (Nielsen Global, 2010) revealed 15.390 out of 27.000 respondents from North America, South America, Asia Pacific, Europe, and the Middle East tend to buy online rather than going to conventional way. Most of companies nowadays in the digital era started to transform their business from brick and mortar to brick and click to capture a massive number of potential online customers. In terms of demographics aspect of internet users it is revealed that the largest proportion of internet users in the United Kingdom (data collected by Office for National Statistic United Kingdom in 2011) belonged to 16-24 years old occupy 98.8 percent. This number represents 7.19 million people, and only 64.000 people in this youngest category had never used the internet. Another survey conducted by (Pew Research Center, 2012) Internet \& American Life Project in 2012 revealed that the largest proportion of internet users in the United States was in the age group of 18 - 29; at 94\% with the margin of error is approximately 2.3 percent. The pattern of largest internet user is quite similar the several developed countries and some of the developing countries. Thus we can construe that the largest proportion of internet user is from in the generation Y. However there is less number of studies correlating the formal technical knowledge of the respondent and their involvement in the e-commerce activities. Especially in Malaysia, relating computer literacy among the respondents in their attitude towards internet usages and e-commerce activities are less researched into. Hence this particular research concentrates on computer literacy influence on e-commerce activities among the $Y$ generation respondents in Malaysia.

\section{Literature Review}

As discuss about Malaysian generation Y, according to Labor Force Survey conducted by Department of Statistic Malaysia in 2008, more than 36\% of labor forces in Malaysia were aged below 30 years old that was about 3.9 million of generation Y. In addition, latest national survey conducted by Department of Statistic Malaysia in 2010 reveals that 57.275 percent of total population or 16.228 .601 out of 28.334 .115 was aged between $0-29$. This group of age can be categorized as generation Y. In term of shopping behavior, 
Malaysian generation $\mathrm{Y}$ spending quite surprising amount, nearly 1.8 billion ringgit annually on online commerce (The Star, 2010). This number might have grown double or triple in the following years. Reflecting this statistics with the current trend, generation $Y$ is looking for more convenient way to shop other than traditional ways. Further the advance information technology also brings positive stimuli when they make purchasing decision (Mansoori, Liat, \& Shan, 2012; Ayupp, Ling, \& Tudin, 2013). The largest number of generation $\mathrm{Y}$ and their familiarity will open a huge opportunity to utilize technology as the media of business in this digital era and captured it.

The modernization today, has brought influenced and changed the world and the way peoples' do in life significantly. The advance technology is changing rapidly and currently people are becoming more dependent to technology. However the attitudes toward technology are not same among people. There are many reasons caused this disparity, and one of the important factors is age (Kubiatko, 2013). According to American Express Business Insight (2012), the research reported that boomers are less ease with technology, but this generation trying to catch up with latest technology. In addition baby boomers believe that their experience is more important to success rather than being technological savvy. According to Rogers (2009) the members of baby boomers are thoughtful adopter and open to new technologies that added value to their life. Generation $\mathrm{X}$ is the digital immigrant. Some members of this generation invented the technology, and they were also the first generation who tasted the fruitful of technology, indeed they are the embryo of today's advance technology (Musings, 2007). Technology is woven into generation X lives, they are also willing to learn and adapt the latest technology, for instance they are comfortable using tablet PC, laptops, and blackberry in order to support their daily activities (Kane, 2014). The millennial, generation members are young, smart and brash. Unlike the predecessor, millennial or generation $\mathrm{Y}$ is walk in the rapid pace, they are both high performance and high maintenance since they are born with the technology (Armour, 2005). This generation consider themselves as technological savvy compared to previous generation. For them technology is vital to their success (American Express, 2012). Millennial have the highest penetration in term of technology such as internet technology, email usage, and social media. Finally this generation has a significant positive view about technology in their life (eMarketer, 2013).

Figure 1: Malaysia Population Pyramid

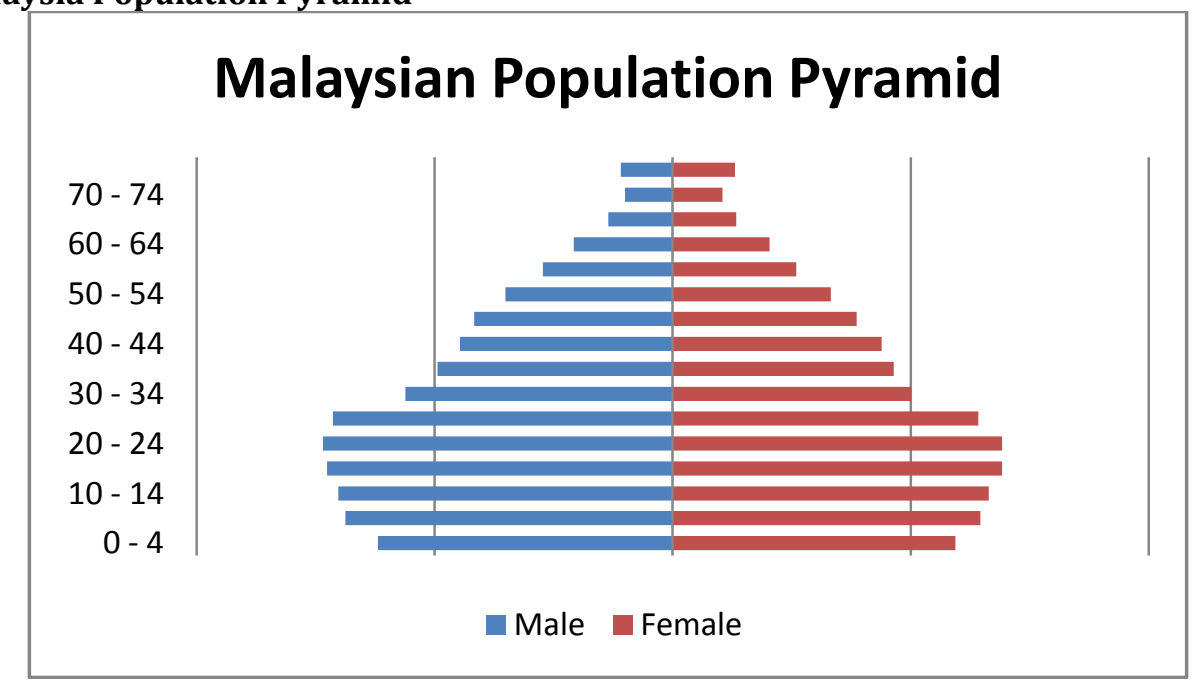

Source: Department of Statistics Malaysia 2010

The attitude towards internet is associated to the user's positive or negative feeling related to the internet activity experience. (Chiu, 2005). This study is assessing user perception of the internet and the effect to ecommerce activities. According to (Kottler, 2004) purchasing decision are influenced by perception, motivation, learning, attitude and belief. The perception is represented by how the users select, organize, and interpret information into form of knowledge. The motivation is represented by users' desire to meet their own need. Learning is reflected by users' behavior arising. Belief is represented by users thought about products or services. Ultimately, attitudes are represented by users' steadily favorable or unfavorable 
assessments, feelings and inclinations towards subject or ideas. Previous study has been done by (Chiu, 2005) found that attitude toward using online application is notably influenced by perceive ease of use. Hence it can be concluded that if the user perception about the application is user friendly then it will lead to positive attitude. Moreover (Crisp, Jarvenpaa, \& Todd, 2007) reveal that positive experience with similar consumer behavior and web technology is the predictive of behavioral intention to purchase products or services through electronic environment (e-commerce). A study conducted by (Jusoh \& Ling, 2012) has revealed that attitude towards internet has significant effect to their e-commerce activities but the numbers users' spend on the internet doesn't effect to their purchasing or selling activities through e-commerce. Ultimately the customer or user perception about e-commerce as well as their experience in the e-commerce bring significant impact to their e-commerce activities.

Computer literacy is associated with the user knowledge and ability to operate computer and other technology related efficiently, with a range of skills covering level from beginner to advance (US Congress of Technology Assessment, 1984), furthermore the computer literacy also related to someone comfort level's using computer application or program. Back in the 70s, the invention time of computer machine, computer literacy involving deep knowledge about computer itself such as, hardware, software, and implication to the society and individual. In the early 80 s computer literacy began resemble today's definition (Johnshon, Anderson, \& Hansen, 1980).

According (National Research Council, 1990) there is three knowledge's required for fluency in the computer literacy:

- Contemporary skill (ability to operate computer application;

- Foundational concept (basic principle of computer); and

- Intellectual capabilities (ability to operate computer in the business field).

By 2000, in the emerging era of internet the computer literacy experienced paradigm shift, computer literacy became wider, literacy include how the computer works, using word processing program, spreadsheet database, utilize the world wide web (WWW). This is the first step emerging computer literacy and information technology. In general user gains the computer literacy in two ways: formally through school or program in the workplace and informally whether at home, from friends or by themselves (Hoffman \& Blake, 2003)

A research done in Turkey, (2005) previously pointed out that significantly high and positive correlation between attitude towards computer and computer literacy among the respondent. But in contrast there was no correlation indicated between attitude towards internet and their computer literacy skill, the lack of Internet access might be a reason for this relationship being weak compare to other component in the research (Yalcinalp, 2005). Another study in Australia 2008 indicated a strong relationship existed between the frequencies of using internet and how they perceive their skill using computer. The better they perceived the better they are using it. This relation was important to online application. The current generation spends most of their computer time online rather than doing traditional computing. The result proves that the higher intensity using internet will make them more computer literate (Gibbs, 2008). Many previous study has tried to indicate that computer literacy was associated with computer technologies, and those who have sufficient computer literacy are tend to involve activities related to internet (Karsten \& Roch, 1998; Delcour \& Kinzie, 1993; Zubrow, 1987). Latest research revealed that there is significantly different between respondent who has basic computer literacy skill and those who doesn't have higher computer literacy skill in their attitude towards internet. Those who have higher computer literacy were enjoying using internet. The study found that there were positive relation between computer literacy and their attitude towards internet (Yanik, 2010).

Currently we are living in the information age, information technology become more prominent to our daily life, thus it become more important to understand the differences between groups of user (Morris \& Venkatesh, 2005). Presently the electronic commerce (e-commerce) experiencing an ever expanding consumer industry, thus to succeed it, it must understand consumer mindset, skill, and attitude towards internet (Oreku \& Mtenzi, 2013). Computer literacy is the amount of computer skill a person acquires over time and has been shown to be both related to attitudes towards computer or internet and their use. (Smith, 
Caputi, Crittenden, Jayasuriya, \& Rawstorne, 1999). In the late 2001, Paynter and Lim pointed out the driver and impediments to e-commerce in Malaysia. According to their research Paynter and Lim suggest gaining ecommerce activities, information technology and internet access had to be widespread across the nation, at that time Malaysia was in the infancy stage of internet particularly on e-commerce and their computer literacy was quite weak compare to developed countries. With the growth of technology in Malaysia peoples' computer skill gradually moving forward. Peoples' perception began to change and fears in e-commerce faded away as they gain understanding of information technology and how to utilize it (Paynter \& Lim, 2001). In the previous year, a study has been done in Singapore to examine the role of computer literacy and their tendency to shop through internet, the result suggests that respondent in Singapore are educated in computers and information technology. Since in Singapore computer literacy is emphasized in their educational system at all levels, the more computer literate individual they would be willing to shop online, even though at that time Singapore was in the infancy level of internet. Computer literate person has a positive view about the internet, and they would tend to be more attracted by attracted by the opportunities of e-marketplace (Liao \& Cheung, 2000). In line with Liao \& Cheung, a research conducted by (Diilllon \& Reif, 2004) revealed that the more experienced user in computer or computer literate exhibited more positive attitude towards internet and online purchasing. Monsuwe, Dellaert, \& Ruyter (2004) emphasizing user personal characteristic such as expertise. Expertise described as individual's level of knowledge or skill. Conducting activites such as e-commerce required a sufficient amount of sufficient amount of computer knowledge or skill. Those who have experienced at e-commerce are most likely to be most skilled user (Ratchford, Talukdar, \& Lee, 2001). A good computer literacy will forming a positive attitude toward shopping on the internet. Consumer with less knowledge of computer or computer literacy will experience uncertainity and less comfortable shopping on the internet.Hence in order to gain positive attitude towards Internet reuquires little computer knowledge. (Monsuwe, Dellaert, \& Ruyter, 2004).

Research framework: Conceptual framework is needed in this study to show possible course of action or presenting preferred approach to an idea thought. In this study deals with the views of technology, general online activities, attitude towards internet, and user computer literacy, ultimately all of this factor will lead to their attitude towards e-commerce. The framework of this idea is illustrated as figure below.

\section{Figure 2: Research Framework}

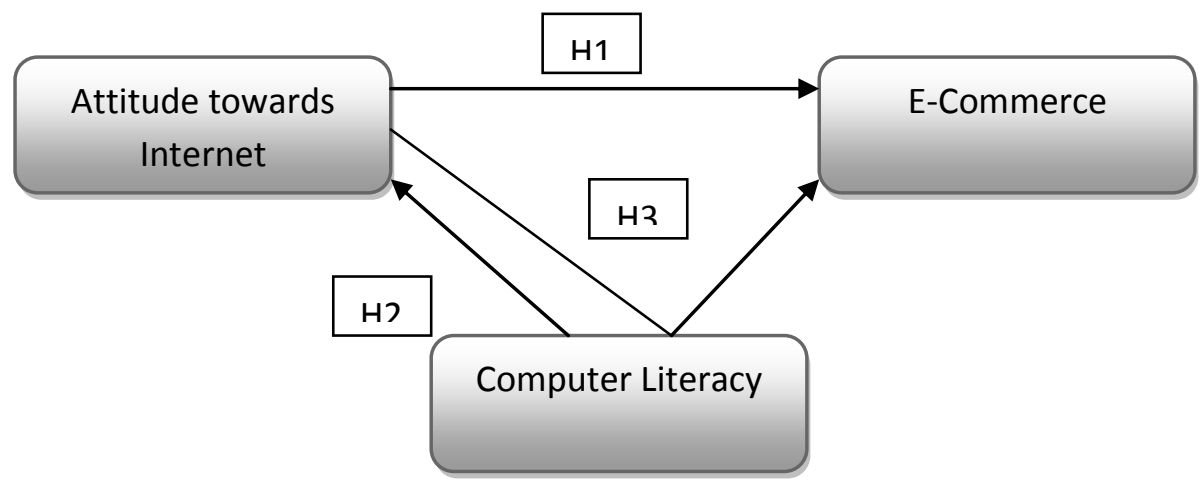

Hypothesis: Once we have identified the important variables in a situation and established the relationships among them through logical reasoning in the theoretical framework, we are in a position to test whether the relationships that have been theorized do in fact hold true. According to Sekaran (2003), hypotheses development done through testing the variable relationship in scientific manner. Researcher will be able to obtain dependable information in which kinds of relationship that exist among the variables operating in the problem situation.

- Generation Y will have affirmative attitude toward internet on their e-commerce activities.

- There will be significant relationship between computer literacy and attitude towards internet among generation $\mathrm{Y}$

- Computer literacy moderating the relationship between attitude toward internet and e-commerce 


\section{Operational Definition}

Generation: Generation, in the daily culture there are two kinds of different meaning of generation, which is referring to kinship and other referring to membership of age group. Meanwhile, in the sociological literature divide generation into two perspectives which is the socio cultural based and cohort historical based. Ultimately, the key term of generation is used in daily term to differentiate and grouping based on age.

Attitude: Attitude is a learned predisposition to behave in a consistently favorable and unfavorable way with respect to a given object. The object in this definition can refer to any person, product, service, brand or marketing concept such as advertising. Attitudes are learned and can be the result of past experience and or information acquired from other people or the mass media (Schiffman, Kanuk, \& Hansen, 2008).

E-commerce: E-commerce (electronic commerce or EC) is the buying and selling of goods and services on the Internet, especially the World Wide Web. In practice, this term and a newer term, e-business, are often used interchangeably. For online retail selling, the term e-tailing is sometimes used.

\section{Methodology}

Unit of Analysis: According to Sekaran (2003), unit of analysis refers to the level of aggregation of the data collected during the subsequent data analysis stage. This research, considered working professionals in Kuala Lumpur and Selangor area as the unit of analysis; hence the unit of analysis in this study is individual. All of them are staffs who are living or work in service companies around Kuala Lumpur and Selangor state.

Research Population: The population of research refers to the entire group of people, event, or things of interest that researcher willing to investigate (Sekaran, 2003). In this particular research, the sample for this research focused on working professional who live around Kuala Lumpur Federal Territory and Selangor State, more precisely the author has selected MSC (Multimedia Super Corridor) landmark such as Cyberjaya, Selangor, TPM (Technology Park Malaysia) and Kuala Lumpur City Centre, since there are lots of office spaces and many local and multinational (MNC) companies were established in Multimedia Super Corridor (MSC) landmark. Multimedia Super Corridor landmark are special territory in Malaysia established in order to accelerate Malaysian economic and transform Malaysia as stated in the vision 2020 as a modern country, with fully adoption of knowledge based. In addition the companies employ definitely knowledge workers round the clock. Further the companies mostly employ worker who is considered as a member of generation $Y$, their age are around 18 to 33 (in the year 2014). According to Lohse, Belman, and Johnson (2000) and Keating (2000) found that the internet users are more likely younger, well educated, and prosperous. Hence Cyberjaya, Technology Park Malaysia (TPM) and Kuala Lumpur City Centre are suitable place to conduct this research

Research Design: Right after identifying the variable in the problem statement and developing the theoretical framework, the following step is designing the research in such a way that the essential data can be gathered and analyzed to arrive at solution (Sekaran, 2003). There are various type of research design, for instance like exploratory study, descriptive study, experimental study. This research is applying descriptive study design in order to ascertain and able to describe the characteristic of the variables in the particular situation. This particular research attempt to investigate the generation $Y$ attitudes towards usage of internet for e-commerce, with one independent variable the attitude toward internet and two moderating variables which are computer literacy and gender. The entire variable were not manipulated or controlled, thus no artificial setting was created. The questionnaire-based survey was used to collect detailed information that reveals the characteristic of generation $\mathrm{Y}$ towards the usage of internet for e-commerce.

Sampling Design: Sekaran (2003) define sampling as the process of selecting the right individuals, objects, or events as representatives for the entire population. There are two major types of sampling design: probability and non probability sampling. In the probability sampling, the elements in the population have some known, non-zero chance or probability of being selected as a sample subjects. While in non probability, the elements do not have known or predetermined chance of being selected as subject. The probability 
sampling design is used when the representativeness of the sample is prominent and wider generalizability (Sekaran, 2003).

The Sampling Method: Determining sampling method is prominent to select the sample in this study. The sampling method can be done in to two different categories: probability and non probability sampling methods. The probability sampling can be either unrestricted (simple random sampling) or restricted (complex probability sampling) (Sekaran, 2003). This survey applies stratified random sampling method. Stratified random sampling involves a process of stratification or segregation, followed by random selection of subject from each stratum (Sekaran, 2003). Proportionate random sampling is used because the sub population within population is vary, the respondent may come from junior level, middle level or even senior management level hence it is beneficial to take samples from each strata. Afterward simple random sampling is applied within each stratum.

Sample Size: Sekaran (2003) define a sample as a small subset of population. A sufficient sample is importantly needed to generalize to the population (Hair, Money, Samouel, \& Page, 2007). Roscoe (1975) proposed that a sample size larger than 30 and less than 500 are required for appropriate research. Barlett, Kotrlik and Higgins (2001) in their research Organizational Survey: Determining Appropriate Sample Size in Survey Research proposed that 200 - 300 sample size is sufficient. In total, ten (confidential) companies in three different areas have selected in order to gain respondent for this particular research and 450 questionnaires has been distributed. The following table shows the distributed questionnaires in the three different areas.

Table 1: Questionnaires Distribution

\begin{tabular}{lllll}
\hline Company & $\begin{array}{l}\text { Junior } \\
\text { Management }\end{array}$ & $\begin{array}{l}\text { Middle } \\
\text { Management }\end{array}$ & $\begin{array}{l}\text { Senior } \\
\text { Management }\end{array}$ & Total \\
\hline $\mathrm{A}$ & 20 & 15 & 5 & 40 \\
$\mathrm{~B}$ & 25 & 15 & 4 & 44 \\
$\mathrm{~B}$ & 35 & 20 & 7 & 62 \\
$\mathrm{D}$ & 30 & 20 & 5 & 55 \\
$\mathrm{E}$ & 25 & 15 & 3 & 43 \\
$\mathrm{~F}$ & 20 & 15 & 5 & 40 \\
$\mathrm{G}$ & 25 & 15 & 4 & 44 \\
$\mathrm{H}$ & 30 & 20 & 5 & 55 \\
$\mathrm{I}$ & 20 & 10 & 4 & 34 \\
J & 20 & 10 & 3 & 33 \\
TOTAL & & & & 450 \\
\hline
\end{tabular}

Measurements

Table 2: Reliability Analysis

\begin{tabular}{ll}
\hline Variable & $\begin{array}{l}\text { Croanbach's } \\
\text { Alpha }\end{array}$ \\
\hline Generational Difference & 0.897 \\
Internet Lifestyle (E-Commerce) & 0.894 \\
Attitude Towards Internet & 0.813 \\
Computer Literacy & 0.848 \\
\hline
\end{tabular}

The table 2 above displays the summary of reliability on the pilot test. Regarding to the initial test or pilot test, it shows that the Croanbach's Alpha for the generational difference is 0.897, while the Croanbach's Alpha for internet lifestyle (e-commerce) is 0.894. The Croanbach's Alpha results for attitude towards internet are 0.813, and ultimately the Croanbach's Alpha for computer literacy is 0.848. Overall the results show that the Croanbach's Alpha exceeding 0.8. Hence, it can be assumed that the internal consistency for this questionnaire is considered to be good. Afterward, the questionnaire can be circulated to the real sample. 
Profile of Respondent: Education: The profile of respondent table shows respondent level of education. Mostly respondents are holding bachelor degree, which accounted 248 respondents or 62 percent. Followed by, respondents who hold master degree which accounted 18 percent out of 100 percent or 72 respondents. The third rank is respondents who have high school or equivalent education which accounted 48 respondents or 12 percent, 28 respondents or 7 percent are holding diploma. Lastly only 4 respondents are holding doctoral degree or 1 percent out of total respondents.

Table 3: Demographic Profile of Respondent

\begin{tabular}{llll}
\hline Demographic & Categories & Total & Percentage (\%) \\
\hline Gender & Male & 208 & 52 \\
Age & Female & 192 & 48 \\
& 25 and under & 296 & 74 \\
Education & $26-33$ & 80 & 20 \\
& $34-40$ years & 52 & 6 \\
& High school or equivalent & 48 & 12 \\
Income & Diploma & 28 & 7 \\
& Bachelor Degree & 248 & 62 \\
Frequency using internet & 72 & 18 \\
& Master Degree & 4 & 54 \\
\multirow{5}{*}{ Wireless utilization } & Doctoral Degree & 216 & 33 \\
& 0- MYR 2000 & 132 & 13 \\
& MYR 2001- MYR 4000 & 52 & 95 \\
& MYR 4001- MYR 6000 & 380 & 3 \\
& Several times a day & 12 & 2 \\
& About once a day & 8 & 97 \\
\hline
\end{tabular}

\section{Result}

This research used multiple regressions analysis in order to test the research hypothesis. The objective of hypothesis testing was to measure how far the connection between dependent variable and independent variables. The significant value was considered as a benchmark to measure significance level or connection between dependent variable and independent variables. If the significant value less than 0.05 can be concluded that there is a significant correlation between independent and dependent variable, thus the null hypothesis or non directional relationship (correlation) is rejected.

Hypothesis 1: Generation $Y$ will have affirmative attitude towards internet on their e-commerce activities.

Table 4: Model summary Generation Y Attitude towards Internet on their E-commerce

\begin{tabular}{llllll}
\hline Model Summaryb & & & & \\
\hline ModelR & $\begin{array}{l}\mathbf{R} \\
\text { Square }\end{array}$ & $\begin{array}{l}\text { Adjusted } \\
\text { Square }\end{array}$ & $\begin{array}{c}\text { RStd. } \\
\text { Estimate }\end{array}$ & Error & of \\
\hline 1 & $.879^{\mathrm{a}} .687$ & .683 & .58475 & & \\
\hline
\end{tabular}

a. Predictors: (Constant), AI

b. Dependent Variable: Ecomm

Model summary table no. 4 above, indicated that $\mathrm{R}$ square value is $0.687\left(\mathrm{R}^{2}=0.687\right)$. It means that 68.7 percent of e-commerce activities are predicted by attitude towards internet, in the meantime, the rest 31.3 percent were predicted by other factors which are not conducted in this research. 
Table5: ANOVA Generation Y Attitude towards Internet on their E-commerce

\begin{tabular}{|c|c|c|c|c|c|c|}
\hline $\begin{array}{l}\text { ANOVA } \\
\text { Model } \\
\end{array}$ & & Sum of & df & Mean Square & $\mathbf{F}$ & Sig. \\
\hline & Regression & 29.989 & 1 & 29.989 & 87.704 & $.000^{\mathrm{b}}$ \\
\hline 1 & Residual & 136.089 & 398 & .342 & & \\
\hline & Total & 166.078 & 399 & & & \\
\hline
\end{tabular}

a. Dependent Variable: Ecomm

b. Predictors: (Constant), AI

The ANOVA table no. 5 above shows that $\mathrm{F}$ value is 87.704 and the significant level value is 0.000 . Followed by the $\mathrm{df}$ (degree of freedom), which represents the number of independent variable is 1 , which is ecommerce and 398 completed responses for the variable. The result shows that there is a significant relationship between attitude towards internet and e-commerce with prediction equation $(\mathrm{F}=87.704, \mathrm{p}<$ 0.05).

Table 6: Coefficient of Attitude towards Internet on E-commerce

\begin{tabular}{|c|c|c|c|c|}
\hline \multicolumn{5}{|c|}{ Coefficients $^{a}$} \\
\hline \multirow[t]{2}{*}{ Model } & \multicolumn{4}{|c|}{ ntsStandardized Coefficientst } \\
\hline & B & Std. Error & Beta & \\
\hline${ }_{1}$ (Constant) & 0.665 & 252 & & 2.638 .00 \\
\hline & .836 & .058 & .829 & 14.507 .000 \\
\hline
\end{tabular}

The coefficient table no. 6 above displays the coefficient level stated in Beta is 0.829 for attitude towards internet variable, which is strong, positive, and significant correlation $(\beta=0.829, p<0.05)$ between attitude towards internet and e-commerce. Hence the result is positive significance between attitude towards internet and e-commerce activities. In conclusion, it has proven that hypothesis 1 (H1), based on the result H1 was accepted. There is a significant relationship between attitude towards internet and e-commerce.

Hypothesis 2: There will be significant relationship between computer literacy and attitude towards internet among generation $\mathrm{Y}$

Table 7: Model Summary Computer Literacy and Attitude towards Internet Model Summaryb

\begin{tabular}{lll}
\hline Model & R & R SquareAdjusted R SquareStd. Error of the Estimate
\end{tabular}

\begin{tabular}{llll}
\hline & $.618^{\mathrm{a}} .473$ & .457 & .84739
\end{tabular}

a. Predictors: (Constant), CL

b. Dependent Variable: AI

Table no. 7 summary on computer literacy and attitude towards internet above shows the R square values is $0.473\left(\mathrm{R}^{2}=0.473\right)$, it means that computer literacy contribute approximately 47 percent of attitude towards internet and the rest 53 percent are predicted by other factors. In addition the $\mathrm{R}$ value is 0.618 , and it is indicating positive value, therefore the relationship between two variables is positive relationship and strong correlation.

Table 8: ANOVA Computer Literacy and Attitude towards Internet ANOVA $^{a}$

Model Sum of Squaresdf Mean SquareF Sig.

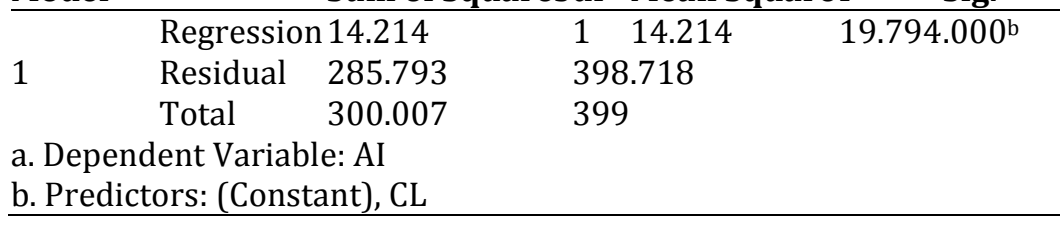


The ANOVA no. 8 table shows that F Value is 19.794 with the significant level 0.000 . Followed by df (degree of freedom) which represent the number of independent variable is 1 which is computer literacy and 398 total completed responses for the variable. The result shows that there is a significant relationship between computer literacy and attitude towards internet with prediction equation $(\mathrm{F}=19.974, \mathrm{p}<0.05)$.

Table 9: Coefficient of Computer Literacy and Attitude towards Internet

\begin{tabular}{|c|c|c|c|c|}
\hline \multicolumn{5}{|c|}{ Coefficients $^{\mathbf{a}}$} \\
\hline \multirow[t]{2}{*}{ Model } & \multicolumn{4}{|c|}{ Unstandardized CoefficientsStandardized Coefficientst } \\
\hline & B & Std. Error & Beta & \multirow[b]{2}{*}{13.104 .000} \\
\hline \multicolumn{2}{|c|}{ (Constant)3.774 } & .288 & & \\
\hline${ }^{1} \mathrm{CL}$ & .717 & .071 & .618 & 4.449 .000 \\
\hline \multicolumn{5}{|c|}{ a. Dependent Variable: AI } \\
\hline
\end{tabular}

The coefficient table no. 9 above display the coefficient level of the Beta is 0.618 for computer literacy variable, and there is strong, positive, and significant correlation $(\beta=0.618, p<0.05)$ between computer literacy and attitude towards internet. Hence the result is positive and there is significant relationship between computer literacy and attitude towards internet. In conclusion, it has proven that hypothesis 2 (H2), based on the result $\mathrm{H} 2$ was accepted, there is a significant relationship between computer literacy and attitude towards internet. In order to gain deeper information about respondent computer literacy skill and their relation with attitude towards internet, in this research respondent were divided into two categories based on their computer literacy skill. In this research we found that 196 respondents had high computer literacy skill, 188 respondents had moderate computer literacy skill, and the rest 18 respondents had low computer literacy skill.

Hypothesis 3: Computer literacy moderate the relationship between attitude toward internet and ecommerce activities

Table 10: Model Summary Computer Literacy Moderate Attitude towards Internet and E-commerce Activities Model Summaryc

ModelR R SquareAdjusted R SquareStd. Error of the Estimate

\begin{tabular}{lccc}
\hline & $.496^{\mathrm{a}} .246$ & .244 & .56105 \\
2 & $.593^{\mathrm{b}} .351$ & .348 & .52099 \\
a. Predictors: (Constant), CL & \\
b. Predictors: (Constant), CL, AI \\
c. Dependent Variable: Ecomm
\end{tabular}

Based on model summary above, table no. 10 shows that model $1 \mathrm{R}$ square value is $0.246\left(\mathrm{R}^{2}=0.246\right)$ which means 24.6 percent e-commerce activities can be predicted by their computer literacy. At the same time, in the model 2 the $R$ square value is $0.351\left(R^{2}=0.351\right)$ which means 35.1 percent of ecommerce activities can be predicted by their attitude towards internet with computer literacy as moderator. In addition when analyze $\mathrm{R}$ value in the model 1 scores 0.496 and 0.593 as in the model 2, it means there is relationship between variables are in positive relationship.

The table no. 11 shows the ANOVA result. The model 1 have F Value for computer literacy is 129.601 and the significance at 0.000 levels. Continued by the $\mathrm{df}$ (degree of freedom) whereby $\mathrm{df}$ represent the number of independent variable is 1 which is computer literacy, and then 398 is total number of complete responses for the variable. While in the model 2 have the $\mathrm{F}$ value for the computer literacy, attitude towards internet are 107.434 , and the significant is 0.000 levels. Followed by the number of independent variable is 2 which is computer literacy, attitude toward internet, then the 397 is total number of complete responses for the variable. The result indicated there is a significant relationship computer literacy moderating attitude towards internet and e-commerce activities with prediction equation, $(F=129.601, p<0.05) \&(F=107.434$, $\mathrm{p}<0.05)$. 
Table11: ANOVA Computer Literacy Moderate Attitude Towards Internet and E-commerce Activities ANOVA $^{a}$

Model

$\begin{array}{ll} & \text { Sum of Squares } \\ \text { Regression } & 40.796\end{array}$

\section{df}

398

399

Total

Regression

2

$\begin{array}{ll}\text { Residual } & 107.757 \\ \text { Total } & 166.078\end{array}$

a. Dependent Variable: Ecomm

b. Predictors: (Constant), CL

c. Predictors: (Constant), CL, AI

\section{7}

399
Mean Square $F \quad$ Sig.

$\begin{array}{lll}40.796 & 129.601 & .000^{\mathrm{b}}\end{array}$

.315

$29.161 \quad 107.434 \quad .000^{c}$

.271

$107.434 \quad .000^{c}$

Table 12: Coefficient of Computer Literacy Moderate Attitude towards Internet and E-commerce Activities

\begin{tabular}{|c|c|c|c|c|}
\hline \multicolumn{5}{|c|}{ Coefficients $^{a}$} \\
\hline \multirow[t]{2}{*}{ Model } & \multicolumn{3}{|c|}{ Unstandardized CoefficientsStandardized Coefficientst } & \multirow[t]{2}{*}{ Sig. } \\
\hline & B & Std. Error & Beta & \\
\hline \multicolumn{2}{|c|}{${ }_{1}$ (Constant)2.553 } & .191 & & 13.387 .000 \\
\hline${ }^{\mathrm{T}} \mathrm{CL}$ & .537 & .047 & .496 & 11.384 .000 \\
\hline (Constant) & 1.618 & .212 & & 7.638 .000 \\
\hline $2 \mathrm{CL}$ & .459 & .045 & .423 & 10.217 .000 \\
\hline AI & .248 & .031 & .333 & 8.035 .000 \\
\hline \multicolumn{5}{|c|}{$\underline{\text { a. Dependent Variable: Ecomm }}$} \\
\hline
\end{tabular}

The coefficient table no. 12 above shows the coefficient level stated in beta. The result is computer literacy have significant influence toward e-commerce activities because the significant level scores 0.000 . In the third hypothesis, computer literacy moderate the attitude towards internet and e-commerce activities. The result shows a significant relation because computer literacy $(\beta=0.423, p<0.05)$ and attitude towards internet $(\beta=$ $0.333, \mathrm{p}<0.05)$. Hence it support the third hypothesis (H3), the computer literacy moderate the attitude towards internet and e-commerce.

Summary of Findings: In this chapter, the entire hypothesis findings are summarized. In the previous section the hypothesis was tested using multiple regression analysis. The benchmark to test the hypothesis is significance level, which is 0.05 . The following table shows the entire hypothesis tested.

Table13: Summary of Findings

\begin{tabular}{lll}
\hline Descriptive & $\begin{array}{l}\text { Generation Y will have affirmative attitude toward } \\
\text { internet on their e-commerce. }\end{array}$ & Accepted \\
H2 & $\begin{array}{l}\text { There will be significant relationship between computer } \\
\text { literacy and attitude towards internet among generation Y }\end{array}$ & Accepted \\
H3 $\begin{array}{l}\text { Computer literacy moderate the relationship between } \\
\text { attitude toward internet and e-commerce }\end{array}$ & Accepted \\
\hline
\end{tabular}

Discussion: This section, discusses each objective that are reviewed and explained with reasonable explanation according to the findings of this study. The results from the findings in this study are important for next Malaysian generation in relation to their computer literacy, attitude towards internet and their ecommerce activities. Since the generation $\mathrm{Y}$ is dominating Malaysian population pyramid and in addition this generation is someway existing and entering workforce and starting to earn money. Furthermore the result may helps to gain deeper understanding of generation Y characteristic in relation with computer literacy, attitude towards internet and lastly e-commerce. This study may contribute to the body of knowledge at academicals level and provide some useful information for e-commerce companies to formulate the strategy in order to boost their sales and focusing on generation $\mathrm{Y}$ consumer. 
Generation $Y$ will have affirmative attitude toward internet on their e-commerce: The first objective in this study was to analyze generation Y attitude towards internet. According to the first hypothesis (H1) test indicates that there is a significant relationship between attitude towards internet and their e-commerce. This study found that Hypothesis (H1) R squared value scores 0.687 , it means that 68.7 percent of ecommerce are predicted by attitude towards internet and the rest 31.3 percent are predicted by other factors. The attitude towards internet itself is related to user's positive or negative perspectives closely knit with their internet activities or experiences. Further the purchasing decision is highly influenced by perception (Kottler, 2004). If the consumers are having positive view about internet technology then there is high possibility to utilize internet for e-commerce activities. Several researches have been done in order to relate the relationship between attitude towards internet and e-commerce. Chiu (2005) has tried to assess the model of online purchase intention and he found that online application such as e-commerce is highly influenced by the site perceive of ease use, or simply the user perception is critical. In line with Chiu (2005), Crisp, Jarvenpaa \& Todd (2007) also found the same findings, they pointed out that positive experience, and positive perspective with similar consumer behavior and web technology is a good predictor of behavioral intention to purchase products or services through electronic environment. Latest research conducted by Jusoh and Ling (2012) reveled attitude towards internet has significant effect to their e-commerce activities. In conclusion the user or customer perspectives about internet, its usage as well as e-commerce bring significant impact to their e-commerce activities.

There will be significant relationship between computer literacy and attitude towards internet among generation Y: The second objective of this study was to examine the relationship between the role of computer literacy and attitude towards internet among generation Y. Based on the hypothesis testing in this study, observe that hypothesis 2 (H2) R squared value scores 0.47 therefore it means that computer literacy predicted moderately high percentage of user attitude towards internet. Moreover the finding indicates that there is a significant relationship between computer literacy and attitude towards internet. Computer literacy is related with the user knowledge and ability to operate computer and other related technology efficiently. In this study respondents come from service companies which are mainly working with IT related tasks. Therefore the respondents score high and moderate on computer literacy skill, leaving only a few of them having low scores on computer literacy skill. Many previous studies has tried to examine the relationship between computer literacy and attitude towards internet. Gibbs (2008) pointed out that the better the user perceived on internet the better they are using it. In his study he also found that there is a strong relationship between frequency on using internet and how they perceive using computer. Since current generation spends most of their time online, the result prove that higher intensity usage will make them computer literate. In line with Gibbs statement Karsten \& Roch (1998), Delcour \& Kinzie (1993), and Zubrow (1987) pointed the same idea, those who have sufficient computer literacy tend to involve more in activities related to internet. In this study based on the computer literacy skill, respondent were divided into three groups: high computer literacy, moderate computer literacy and low computer literacy. Based on the test shows that there is significant difference between those who has greater computer literacy and lower computer literacy. For those who have moderate computer literacy skill indicates insignificant relationship between computer literacy and attitude towards internet and those who has high computer literacy skill indicates significant relationship between attitude towards internet and computer literacy. This finding is supported by Yanik (2010), which is pointed out that those who have higher computer literacy were the one more enjoying internet usage, and the opposite. The study found that there is positive relationship between computer literacy and their attitude towards internet.

Computer literacy moderate the relationship between attitude toward internet and e-commerce: The third objective was to examine the moderating effect of the role of computer literacy in its attitude towards internet and e-commerce. The result shows that the computer literacy moderates the attitude towards internet and e-commerce. Computer literacy is the amount of computer skill a person acquires overtime and has been shown to be both related to attitude towards computer or internet and their use (Smith, Caputi, Crittenden, Jayasuriya, \& Rawstorne, 1999). This finding is supported by previous study conducted in Singapore in the year 2000. The study conducted by Liao and Cheung (2000) has tried to examine the role of computer literacy and e-commerce. They pointed out that computer literate person has a positive view about the internet, and they would tend to be more attracted by the opportunities of e-marketplace. In addition Dillon and Reiff (2004) revealed that the more experienced user in computer or computer literate user 
exhibited more positive attitude towards internet and online purchasing. In this study respondents were working professional from service companies who works mainly with IT related tasks, therefore the respondents mostly having a good computer literacy, only a few of them scores low on computer literacy skill. Thus they had a positive view about attitude towards internet and e-commerce activities. Hypothesis testing proves that computer literacy skill moderate attitude towards internet and e-commerce.

Implications: There are some implications for policy level, managerial level, as well as for the body of knowledge in the future research; in order to boost e-commerce especially focuses on the next generation.

Policy Level: This study provides a better understanding on generation $Y$ attitude towards usage of internet for e-commerce. This study reveals that attitude towards internet contribute a large portion to e-commerce. The more positive attitude towards internet, more intense the e-commerce activities. The policy makers, in this case, Ministry of Trading, Ministry of Education and Malaysia Communication and Multimedia Commission (MCMC) should facilitate people of Malaysia to have better training and development initiatives that provide more understanding about internet itself, and with its usage more online consumer purchasing behavior. The customers can act as better online shoppers and government initiatives can control customer congestions in the retail and shopping malls. Government can act as better facilitator to gain technology skills to their present and upcoming generations and further influence their e-commerce activities. Moreover the government should provide stimulus to small medium enterprise (SME) to transform and innovate their business through provide e-commerce.

Managerial level: This study provides information about generation $Y$ attitude towards usage internet for ecommerce. Y generation spending pattern is incredibly high, and they are techno savvy people. In addition generation Y currently entering the workforce and started their earning life. The consumption most probably will be at higher as well. For companies which involve in electronic commerce, this study will provide wonderful information about generation Y. Therefore the companies may plan effective strategies in order to get more customers, especially from generation Y. For those companies, which have established brick, and mortar, in the future they may provide online services, transforming into brick and click, further support to enhance their business, ultimately getting more customers from generation $\mathrm{Y}$.

Theoretical: In the theoretical field, this study adds up a small portion of information to the literature about generation $Y$, attitude towards internet and electronic commerce. Currently there is limited resource focus on e-commerce and generation $Y$ in Malaysian scenario. This study may provide an insight to the future research, adding up existing literature with recent findings that support academicians and research scholars to conduct deeper research on e-commerce and generation Y.

\section{Conclusion}

In the recent years, the trend of internet usage has been increased tremendously. This phenomenon has contributed a great impact to business sector and individuals. The great number of internet users has attracted business to transform their business into digital. The millennial or generation Y, commonly referred as digital native, since their characteristic, which is familiar to technology. Technology is the second environment to this generation. Furthermore generation $Y$ are dominating the pyramid of population almost all over the world inclusively Malaysia, currently the generation $Y$ is entering workforce and start earning money. In addition this spending pattern of this generation is quite surprisingly, nearly 1.8 billion ringgit annually only in e-commerce. This generation is looking for more convenient way to shop instead doing conventional way. A huge number of Malaysian generation $\mathrm{Y}$ and their familiarity will open a huge opportunity to utilize technology as the media of business in this digital era that captured the trend. This particular study is aimed to examine attitude towards the usage of internet for e-commerce among generation Y. It is clearly observed that there is significant relationship between attitude towards internet and e-commerce activities. Factors such as gender and computer literacy in this study play a major role as moderator towards internet usage behavior. Further the relationship between gender and computer literacy as a moderator highly significant observed. Studies further extended across Malaysia further to understand the reliability Malaysian consumers attitude towards technology adoption and purchasing behavior. 


\section{References}

American Express. (2012). American Express Business Insight. New York: American Express.

Ayupp, K., Ling, L. N. \& Tudin, A. (2013). An Analysis of Luxury Products Purchasing Behavior of Malaysian University Students. Asian Journal of Social Sciences and Humanities, 2(4), 219-227.

Bartlett, J. E., Kotrlik, J. W. \& Higgins, C. C. (2001). Organizational Research: Determining Appropriate sample Size in Survey Research. Information Technology, Learning, and Performance Journal, 19(1), 43-50 (Spring).

Chiu, Y. B. (2005). Gender differs: assessing a model of online purchase intentions in e-tail service. International Journal of Service Industry Management, 16(5), 416-435.

Crisp, C. B., Jarvenpaa, S. L. \& Todd, P. A. (2007). Individual Differences and Internet Shopping Attitude and Intentions. http://www.informationr.net/ir/12-2/Crisp.html.(Retrieved on 21st January 2014)

Delcour, M. A. \& Kinzie, M. B. (1993). Computer technologies in teacher education: The measurement of attitudes and self-efficacy. Journal Research and Development in Education, 27, 35-41.

Diilllon, T. W. \& Reif, H. L. (2004). Factors Influencing Consumers' E-Commerce Commodity Purchases. Information Technology, Learning, and Performance Journal, 22(2).

Gibbs, S. (2008). Internet use equals computer literacy? Proceedings ascilite. Melbourne.

Hair, J., Money, A., Samouel, P. \& Page, M. (2007). Research Method for Business. John Willey \& Sons, Ltd.

Hoffman, M. \& Blake, J. (2003). Computer Literacy Today and Tomorrow. Journal of Computing Sciences in Colleges, 18(5), 221-233.

Johnshon, D. C., Anderson, R. E. \& Hansen, T. P. (1980). Computer Literacy - What is it? The Mathematics Teacher.

Jusoh, Z. M. \& Ling, G. H. (2012). Factor Influencing Consumers' Attitude Towards E-commerce. International Journal of Humanities and Social, 2(4), 223-230.

Karsten, R. \& Roch. (1998). The relationship of computer experience and computer self-efficacy to performance in introductory computer literacy courses. Journal of Research on Technology Education, 31(1) 14-24

Keating, L. (2000). The in crowd: retail rushes to keep pace with generation y. Shopping Center World .

Kottler, A. (2004). Principles of Marketing. New Jersey: Prentice Hall.

Kubiatko, M. (2013). The Comparison of Different Age Groups on the Attitudes. Educational Sciences: Theory \& Practice, 13(2), 1623.

Liao, Z. \& Cheung, M. T. (2000). Internet-based e-shopping and consumer attitudes: an empirical study. Information \& Management, 38(5), 299-306.

Lohse, G., Bellman, S. \& Johnson, E. (2000). Consumer Buying Behavior on the Internet. Journal of Interactive Marketing, 14(1), 15-29.

Malaysia Crunch. (2010). Malaysia's E-Commerce Statistics. URL: http://www.malaysiacrunch. com/2012/03/malaysias-e-commer ce-statistics-updated.html. (Retrieved on 24th February 2014)

Mansoori, S., Liat, C. B. \& Shan, L. H. (2012). A Study Of E-Shopping Intention In Malaysia: The Influence Of Generation X \& Y. Australian Journal of Basic and Applied Sciences, 6(8), 28.

Monsuwe, T. P., Dellaert, B. G. \& Ruyter, K. D. (2004). What drives consumers to shop online? A literature review. International Journal of Service Industry Management, 15(1), 102-121.

Morris, M. \& Venkatesh, V. (2005). Gender and age differences in employee decisions about new technology: an extension to the theory of planned behavior. Engineering Management, 52(1), 69-84.

National Research Council. (1990). Being Fluent with Information Technology. Washington, D.C.: National Academy Press.

Nielsen Global. (2010). Trends in online shopping. New York.

Oreku, G. S. \& Mtenzi, F. J. (2013). A Viewpoint of Tanzania E-Commerce and Implementation Barriers. ComSIS .

Pew Research Center. (2012). Internet \& American Life Project. Washington, DC.

Ratchford, B., Talukdar, D. \& Lee, M. S. (2001). A model of consumer choice of the internet as information source. International Journal of Electronic Commerce, 5(3), 7-21.

Roscoe, J. (1975). Fundamaental Research Statistics for The Behavioral Science. New York: Rinehart and Winston.

Sekaran, U. (2003). Research Methods for Business: A Skill Building Approach. John Wiley \& Sons, Incorporated. 
Smith, B., Caputi, P., Crittenden, N., Jayasuriya, R. \& Rawstorne, P. (1999). A Review of The Construct of Computer Experience. Computers in Human Behaviour, 15(2), 227-242.

US Congress of Technology Assessment. (1984). Computerized Manufacturing Automation: Employment, Education and the Workplace. Washington.

Yalcinalp, S. (2005). A Study of Students' Self-Efficacy, Performance and Attitudes Towards Computers and Internet in a Computer Literacy Course at Freshman. European Conference on Educational Research.

Yanik, C. (2010). The Relationship Between Prospective Teacher's Computer Literacy And Their Attitude Toward Internet. Journal of Education, 39(1), 371-382.

Yvonne R., Hazlewood, W. R., Paul, M. P., Nick, D. \& Susanna, H. (2010). Ambient influence: can twinkly lights lure and abstract representations trigger behavioral change? In: Proceedings of the 12th ACM international conference on Ubiquitous computing, (UbiComp'10) 26-29 Sep 2010, New York, NY, USA, 261-270.

Zubrow, D. (1987). How Computing Attitudes Change During The Freshman Year. Computing and Change on Campus , 3, 195-211.

Dillon, T. W. \& Reif, H. L. (2004). Factors Influencing Consumers' E-Commerce Commodity Purchases Information Technology. Learning and Performance Journal, 22(2), 1-12.

Bartlett, J. E., Kotrlik, J. W. \& Higgins, C. C. (2001). Organizational Research: Determining Appropriate sample Size in Survey Research. Information Technology, Learning, and Performance Journal, 19(1), 43-50 (Spring).

Schiffman, L. G. \& Kanuk, L. L. (2007). Consumer Behavior (9th ed.). Upper Saddle River, N.J.: Pearson Prentice Hall.

Rogers, M. (2009). Boomers and technology: An extended conversation. Retrieved from http://assets.aarp.org/www. aarp.org_/articles/computers/2009_boomers_and_technology_final_report.pdf

Paynter, J. \& Lim, J. (2001, December). Drivers and impediments to e-commerce in Malaysia. Malaysian Journal of Library \& Information Science, 6(1), pp. 1-19.

Armour, S. (2005). Generation Y. They arrive in the workplace with a new attitude. Retrieved March 2014, 25, from USA Today: http://usatoday30.usatoday.com/educate/college /careers/Hot/11-7-05b.htm

Musings, M. (2007). Digital natives, digital imrnigrants...what about digital Pilgrims? URL: http://blogs.computerworld.com/digital_natives_digital_immigrants_what_about_digital_pilgrims. (Retrieved on 20th January 2014) from Computerworld Blogs.

eMarketer. (2013). How Digital Behavior Differs Among Millennials, Gen Xers and Boomers. URL:http://www.emarketer.com/Article/How-Digital-Behavior-Differs-Among-Millennials-GenXers-Boomers/1009748. (Retrieved on 1st March 2014)

eMarketer. (2013). For Digital Shopping, Baby Boomers Favor Desktop Over Mobile. Retrieved March 25, 2014, from eMarketer: www.emarketer.com/Article/Digital-Shopping-Baby-Boomers-FavorDesktop-Over-Mobile/1010130.Retrieved on 1st February 2014)

Kane, S. (2014). Generation X. URL: http://legalcareers.about.com/od/practicetips/a /GenerationX.htm.(Retrieved on 21st January 2014), from Legal Careers

The Star (Sept 28 ${ }^{\text {th }}$ 2014). Malaysias Consumer Statistics (Updated). News paper report. 